\title{
Antibacterial Activity and Screening of Antibacterial Compounds of Costus pictus D.Don Using GC-MS
}

\author{
Ramya $\mathbf{R}^{1}$, Dhamotharan $\mathbf{R}^{2}$ \\ ${ }^{1}$ Assistant Professor, Department of Biochemistry, J.B.A.S College for Women, Teynampet ,Chennai - 600018, India \\ ${ }^{2}$ Associate Professor, PG \& Research Department of Botany, Presidency College, Triplicane, Chennai - 600005, India
}

\begin{abstract}
The medicinal plants are the reservoiur of potential microbial compounds that are useful as an alternative to synthetic microbicides and are used to develope drugs. In the present study an ethanomedicinal plant Costus pictus was analysed for preliminary phytochemical screening, GCMS and antimicrobial activity. The phytochemical analysis revealed the presence of active compounds such as phenols, flavonoids, tannins, terpenoids, alkaloid, steroids, glycosides and saponin in the ethanol leaf extract of costus pictus . Different concentration of ethanolic leaf extracts were tested using disc diffusion technique for the activity against Bacillus cereus, Pseudomonas aeruginosa, Staphylococcus aureus, Escherichia coli and Bacillus subtilis. The ethanolic leaf extract showed concentration-dependent activity at various concentrations against all tested bacterias expect E.coli with the zone of inhibition. GC-MS analysis also confirmed the presence of bioactive compounds. The powerful antibacterial effect is attributed due the presence of active compounds present in the ethanolic leaf extract of Costus pictus.
\end{abstract}

Keywords: Phytochemical, antimicrobial, disc diffusion, Concentration -dependent, GC-MS analysis

\section{Introduction}

Medicinal plants are the valuable source of natural active compounds for maintaining human health and treatment of many human diseases. The bioactive compounds are alkaloids, phenols, tannins, flavonoids, vitamins and minerals which are found to have antioxidant, antitumour, antibacterial, anticarcinogenic and diuretic properties. [1][2] Therefore there is a need to study the ethnomedicinal use and importance of herbal medicinal plants in the discovery of novel drugs. Most of the synthetic drugs used to cure human aliments have their origin from plant products.[3]

Costus pictus D.Don, ommonly known as fiery costus, spiral ginger, step ladder or insulin plant is a native of south and central America.[4] In India the plant is grown as ornamental plant especially in Kerala.[5] The plant is used in India as an herbal cure for diabetes hence commonly called as "Insulin plant". [6] It is an perennial erect herb growing up to three meters tall and leaves arranged spirally around the stem. The plant belongs to the family costaceae. The plant can be cultivated either by stem cutting or vegetative propagation.

In India the plant is used to control diabetes, people consume one leaf daily to keep their blood sugar level low.[7] It is also reported to have anti-inflammatory and hypoglycemic action. [8] The parts of the plant are used in the treatment of renal disorders and possess diuretic activity. [9] Several studies have been carried out in the leaf extract of Costus pictus to evaluate the antidiabetic properties. [10] The leaf and the rhizome are known for the antidiuretic, antihelmintic, antibacterial and antitumour activities. [11] The present study was undertaken to study the antibacterial activity of the leaf extract of Costus pictus. Phytochemical screening and GCMS analysis were also performed.

\section{Materials and methods}

\section{Plant Material}

Fresh healthy plants of Costus pictus was collected from Kerela and brought to the laboratory after identification. Fresh leaves were washed under running tap water, shade dried at room temperature and then homogenized to fine powder and stored in air tight bottles.

\section{Test organism used}

The test microorganism like Bacillus subtilis, Bacillus cereus, Pseudomonas aeruginosa, Staphylococus aureus and Escherichia coli were collected from MTCC. All the bacterial strains were suspended in nutrient broth and incubated at $37 \mathrm{C}$ for $24 \mathrm{hrs}$.

\section{Preparation of Plant extract}

Preparation of the extracts was done by the following method. One gram of dried powder of plant materials was extracted with $20 \mathrm{ml}$ of ethanol (75\%), acetone, chloroform, aqueous and petroleum ether (Merck, extra pure) for $1 \mathrm{~min}$ using an Ultra Turax mixer $(13,000 \mathrm{rpm})$ and soaked overnight at room temperature. The sample was then filtered through Whatman No. 1 filter paper in a Buchner funnel. The filtered solution was evaporated under vacuum in a rotavator at $40^{\circ} \mathrm{C}$ to a constant weight and re dissolved in the same solvent namely aqueous, ethanol, chloroform, petroleum ether and acetone for extraction. The solution was stored at $18^{\circ} \mathrm{C}$ for further studies.

\section{Phytochemical Screening}

Phytochemical screening was carried out for analysing the secondary metabolites which are responsible for curing various human aliments. The phytochemical screening of the leaf extract was accessed by the standard method. [12] [13] [14] to detect the presence or absence of certain bioactive compounds. Five different solvent extracts were used to 


\section{International Journal of Science and Research (IJSR) \\ ISSN (Online): 2319-7064 \\ Index Copernicus Value (2013): 6.14 | Impact Factor (2015): 6.391}

identify the major natural chemical compounds such as tannins, saponins, flavonoids, phenols, terpenoids, alkaloids, glycosides and steroids.

\section{GC-MS Analysis}

For the Identification of bioactive components, the extract was subjected to GC-MS analysis. GC-MS analysis was carried out on a GC-MS -5975C agilent system comprising an auto sampler and a gas chromatograph interfaced to a mass spectrometer (GC-MS) instrument, employing the following conditions: column Elite-1 fused silica capillary column $(30 \times 0.25 \mathrm{~mm}$ ID $\times 1 \mathrm{EM} \mathrm{df}$, composed of $100 \%$ Dimethyl poly siloxane), operating in electron impact mode at $70 \mathrm{eV}$; helium $(99.999 \%)$ was used as carrier gas at a constant flow of $1.51 \mathrm{ml} / \mathrm{min}$ and an injection volume of $1 \mu \mathrm{l}$ was employed (split ratio of 10:1) injector temperature 2400C; ion-source temperature 2000C. The oven temperature was programmed from $700 \mathrm{C}$ (isothermal for 2 $\mathrm{min}$ ), with an increase of $100 \mathrm{C} / \mathrm{min}$, to $3000 \mathrm{C} / \mathrm{min}$, ending with a 9 min isothermal at 3000C. Mass spectra were taken at $70 \mathrm{eV}$; with a scan range $40-1000 \mathrm{~m} / \mathrm{z}$. Solvent cut time was $5 \mathrm{~min}$; MS start time being $5 \mathrm{~min}$; MS end time being $35 \mathrm{~min}$; Ion source temperature set to $2000 \mathrm{C}$ and interface temperature being $2400 \mathrm{C}$.

\section{Identification of Components}

Interpretation of mass spectrum of GC-MS was done using the database of National Institute Standard and Technology (NIST) having more than 62000 patterns. The mass spectrum of the unknown component was compared with the spectrum of the known components stored in the NIST library. The name, molecular weight and structure of the component of the test materials were identified.

\section{Anti-bacterial activity \\ The ethanol leaf extract of Costus pictus was used for antibacterial study.[16] [17] Different concentrations (10mg, $20 \mathrm{mg}$ and $30 \mathrm{mg} / \mathrm{ml}$ ) of the concentrated ethanol leaf extract was tested for its antimicrobial activity against pathogenic bacterial strains such as Bacillus subtilis, Staphylococcus aureus, Bacillus cereus, Escherichia coli and Pseudomonas aeruginosa. The bacterial cultures were grown in Mueller Hinton Agar and Mueller Hinton Broth (Himedia).[18]}

\section{Antibacterial activity assays}

Antibacterial activity was measured using the standard method of diffusion disc plates on agar.[19] For antimicrobial assay, all bacterial strains were grown in Mueller HintonBroth Medium (Himedia) for 24 hours at $37^{\circ}$ $\mathrm{C}$ and plated on Mueller Hinton Agar (Himedia) for agar diffusion experiments. Then $0.1 \mathrm{ml}$ of each culture of bacteria was spread on agar plate surfaces. Sterile disc (Hi Media, $6 \mathrm{~mm}$ in diameter) were placed on the agar medium to load $20 \mu \mathrm{l}$ of different concentration $(10-30 \mathrm{mg} / \mathrm{ml})$ of ethanolic leaf extracts of Costus pictus was tested. Inhibition diameters were measured after incubation for 24 hours at $37^{\circ} \mathrm{C}$. Blanks of solvent only (processed in the same way), were also tested for antibacterial activity.

\section{Minimum inhibitory concentration}

Minimum inhibitory concentration (MIC) of leaf extract against both the bacteria (Bacillus cereus and Pseudomonas aeruginosa) was assessed by serial dilution method. Ten different concentrations of the ethanolic extract of Ccostus pictus $(0.1 \%, 0.2 \%, 0.3 \%, 0.4 \%, 0.5 \%, 0.6 \%, 0.7 \% 0.8 \%$, $0.9 \%, 1.0 \%$ ) were incorporated into nutrient broth in different test tubes. In each test tube, $5 \mathrm{ml}$ of extract was added to $4.9 \mathrm{ml}$ of nutrient broth and $0.1 \mathrm{ml}$ of bacterial culture. A control tube containing the growth medium and the bacteria was set-up. The mixtures were incubated at $37^{\circ} \mathrm{C}$ for $24 \mathrm{~h}$ and analyzed for turbidity. The minimum concentration of leaf extract that will inhibit the growth of the microorganism was determined as MIC.

\section{Results}

\section{Phytochemical screening}

In the present study phytochemical screening was performed with aqueous, ethanol, chloroform, acetone and petroleum ether. The ethanolic leaf extract of Costus pictus was found to be rich in terpenoids, Quinones, glycosides, alkaloids, flavonoids, steroids, Phenols, tannins and saponins followed by other extracts. The results were presented in the Table 1.

\section{GC-MS Analysis}

Gas Chromatography -Mass Spectrometry is a potent tool for identifying the bioactive compounds present in the natural product. The GC-MS chromatogram of Costus pictus showed twenty three peaks indicating the presence of twenty chemical constituents. The twenty chemical constituents were characterised and identified on comparison of the mass spectra of the constituents with the NIST library. The active compounds with their retention time, molecular formula, molecular weight and peak area $(\%)$ are presented in the Table 2. GC-MS analysis revealed the presence of active metabolites comprising of fatty acids, alcohols, methylesters, terpenoids, alkaloids and heterocyclic compounds. Out of twenty compounds identified major components were Vitamin E(20.47\%), Gamma Tocopherol(12.08\%)

\section{Antibacterial assay}

The ethanolic leaf extract of Costus pictus were tested for the antimicrobial activity against Bacillus subtilis, Bacillus cereus, Pseudomonas aeruginosa, Staphylococcus aureus and Escherichia coli and the results are presented in Table 3. The ethanolic leaf extract shows activities against all test organisms except Escherichia coli.

\section{Discussions}

In the present study, the phytochemical screening of leaf extract of Costus pictus showed that, among the five different solvent extracts, the ethanolic leaf extract was found to be rich in Tannins, Saponins, Flavonoids, Quinones, Glycosides, Terpenoids, Phenols, Steroids, Alkaloids followed by other extracts.

Phytochemical constituents such as tannins, flavonoids, alkaloids and several other aromatic compounds are secondary metabolites that serve as defence mechanism against many microorganisms [20]

Flavonoids are potent water soluble antioxidants which prevent oxidative cell damage and possess anticancer

\section{Volume 5 Issue 6, June 2016}




\section{International Journal of Science and Research (IJSR) \\ ISSN (Online): 2319-7064 \\ Index Copernicus Value (2013): 6.14 | Impact Factor (2015): 6.391}

activity and anti inflammatory activity. [21] Tannins are found to have anti bacterial, antiulcer and antiviral properties. [22] In the present study the antimicrobial activity is mainly attributed due to the presence of phenolic compound, tannin and saponins.[23] (24] The ethanolic crude extract showed inhibitory activity against gram positive and gram negative bacteria. [25] The ethanolic leaf extract shows activity against Baicllus, Subtilis, Bacillus Cereus, Pseudomans aeruginosa, Staphylococcus auerus but no activity against $E$ Coli. The bioactive compounds present in the extract elicite the antibacterial activity against microorganism.

The antimicrobial potential of Costus pictus was tested by using agar well diffusion method. The ethanol extract of Costus pictus $(30 \mathrm{mg} / \mathrm{ml})$ showed maximum zone of inhibition $(13 \mathrm{~mm})$ against Pseudomonas aeruginosa where as Staphylococcus aureus showed less zone inhibition $(9 \mathrm{~mm})$. E. coil does not show any activity against any concentration.

Further GC - MS analysis of the plant extract has established 23 bioactive compounds which possess several pharmacological properties. Phytochemical screening and GC-MC studies confirm presence of phenolic compound mainly responsible for the antimicrobial property of the plant.

The present study unveil the medicinal important of bioactive compounds present in the ethanol extract of Costus pictus. The antibacterial properties of the extract may be due to the presence of above mentioned phytochemicals

\section{Acknowledgement}

The first author is thankful to Poonga Biotech Research Centre, Plant biotechnology division, Chennai-600113,
Tamil Nadu India for providing the necessary laboratory facilities.

\section{Conclusion}

The medicinal plant screened was found to be rich in secondary metabolites which are used in traditional medicine to combat and cure various diseases.

Phytochemical analysis showed that antibacterial activity of Costus pictus was due to the presence of phytochemical such as Tannins, Saponins and Phenols. Thus the plant can be utilized as an useful source to formulate new antimicrobial drugs of natural origin. Further studies are needed to isolate and characterize the structure of bio active compounds for drug formulation.

Table 1: Phytochemical screening of Costus pictus

\begin{tabular}{|c|c|c|c|c|c|}
\hline \multirow[b]{2}{*}{ Phytochemicals } & \multicolumn{5}{|c|}{ Leaf extract } \\
\hline & Aqueous & Ethanol & chloroform & Acetone & $\begin{array}{c}\text { Petroleum } \\
\text { ether }\end{array}$ \\
\hline Tannins & + & + & - & + & + \\
\hline Saponins & - & + & - & - & - \\
\hline Flavonoids & + & + & - & + & - \\
\hline Quinones & + & + & + & + & + \\
\hline Glycosides & - & + & - & - & - \\
\hline $\begin{array}{c}\text { Cardiac } \\
\text { glycosides }\end{array}$ & - & + & - & + & + \\
\hline Terpenoids & + & ++ & + & + & + \\
\hline Phenol & + & ++ & + & + & + \\
\hline Alkaloids & + & + & - & + & - \\
\hline Steroids & + & ++ & + & + & + \\
\hline Betacyanin & + & + & - & + & - \\
\hline Anthocyanin & - & - & - & - & - \\
\hline
\end{tabular}

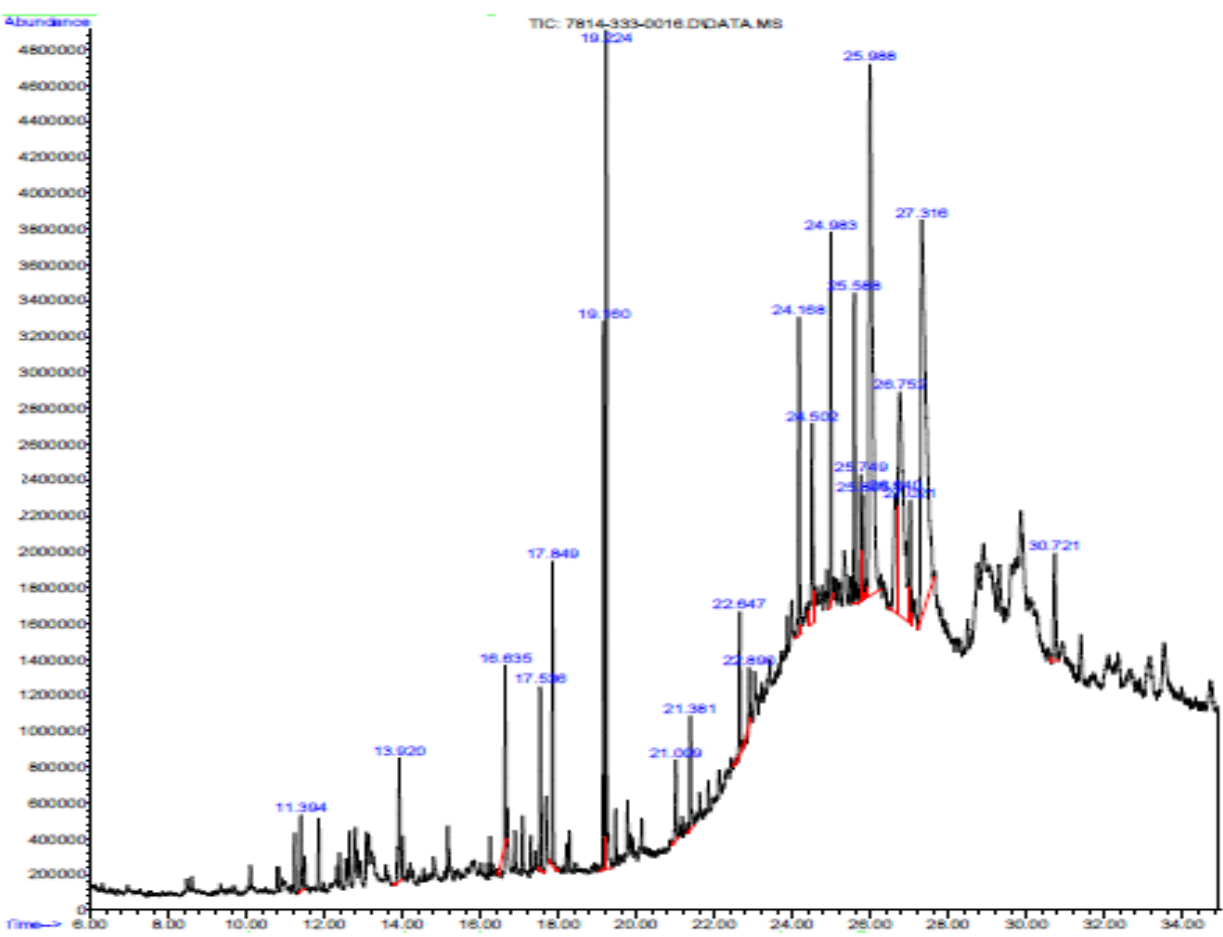

Figure 1: Shows GC-MS Chromatogram of Costus pictus

Volume 5 Issue 6, June 2016 www.ijsr.net

Licensed Under Creative Commons Attribution CC BY 


\section{International Journal of Science and Research (IJSR) \\ ISSN (Online): 2319-7064}

Index Copernicus Value (2013): 6.14 | Impact Factor (2015): 6.391

Table 2: Phytocomponents identified in Costus pictus by GC-MS analysis

\begin{tabular}{|c|c|c|c|c|}
\hline RT & Area Percentage & Name & Molecular Formula & Molecular structure \\
\hline 13.919 & 1.74 & caryophyllene oxide & $\mathrm{C}_{15} \mathrm{H}_{24} \mathrm{O}$ & 220.35046 \\
\hline 16.638 & 0.67 & Bicyclo[3.1.1]heptane, 2,6,6-trimethyl- & $\mathrm{C}_{10} \mathrm{H}_{18}$ & 138.2499 \\
\hline 17.537 & 1.67 & Hexadecanoic Acid & $\mathrm{C}_{17} \mathrm{H}_{34} \mathrm{O}_{2}$ & 256.43 \\
\hline 17.849 & 2.86 & Dibutyl Phthalate & $\mathrm{C}_{16} \mathrm{H}_{22} \mathrm{O}_{4}$ & 278.35 \\
\hline 19.164 & 4.71 & $9,12-$-Octadecadienoic acid (Z,Z)-, methyl ester & $\mathrm{C}_{19} \mathrm{H}_{34} \mathrm{O}_{2}$ & 294.4721 \\
\hline 21.006 & 0.94 & Nonadecane & $\mathrm{C}_{19} \mathrm{H}_{40}$ & 268.518 \\
\hline 22.648 & 1.33 & Eicosane & $\mathrm{C}_{20} \mathrm{H}_{42}$ & 282.54748 \\
\hline 22.893 & 0.39 & Bis(2-ethylhexyl) phthalate & $\mathrm{C}_{24} \mathrm{H}_{38} \mathrm{O}_{4}$ & 390.56 \\
\hline 24.170 & 3.27 & Heptadecane & $\mathrm{C}_{17} \mathrm{H}_{36}$ & 240.48 \\
\hline 24.505 & 3.21 & $9,12-$ Octadecadienoic acid (Z,Z) & $\mathrm{C}_{18} \mathrm{H}_{32} \mathrm{O}_{2}$ & 280.4455 \\
\hline 24.980 & 3.40 & Squalene & $\mathrm{C}_{30} \mathrm{H}_{50}$ & 410.73 \\
\hline 25.589 & 3.21 & Eicosane & $\mathrm{C}_{20} \mathrm{H}_{42}$ & 282.54748 \\
\hline 25.753 & 1.79 & Piperine & $\mathrm{C}_{17} \mathrm{H}_{19} \mathrm{NO}_{3}$ & 285.34 \\
\hline 25.805 & 1.27 & pentamethyl-3,7,11,15,19-heneicosapentaenyl)-, & $\mathrm{C}_{30} \mathrm{H}_{50} \mathrm{O}$ & 426.7174 \\
\hline 26.637 & 3.73 & (all-E) & $\mathrm{C}_{28} \mathrm{H}_{48} \mathrm{O}_{2}$ & 416.68 \\
\hline 26.748 & 12.08 & Beta Tocopherol & $\mathrm{C}_{28} \mathrm{H}_{48} \mathrm{O}_{2}$ & 416.68 \\
\hline 27.313 & 20.47 & Gamma Tocopherol & $\mathrm{C}_{28} \mathrm{H}_{48} \mathrm{O}_{2}$ & 430.7061 \\
\hline 30.722 & 2.31 & Vitamin E & ${\mathrm{C} 9 \mathrm{H}_{9} \mathrm{~N}_{3} \mathrm{O}}^{2}$ & 207.18606 \\
\hline
\end{tabular}

Table 3: Antibacterial activity of ethanol leaf extract of Costus pictus

\begin{tabular}{|c|c|c|c|}
\hline \multicolumn{3}{|c|}{ Inhibition Zone in diameter $(\mathrm{mm})^{*}$} \\
\hline Micro-organisms Tested & \multicolumn{3}{|c|}{ Concentrations of extract } \\
\hline Leaf extract & $10 \mathrm{mg} / \mathrm{ml}$ & $20 \mathrm{mg} / \mathrm{ml}$ & $30 \mathrm{mg} / \mathrm{ml}$ \\
\hline Bacillus subtilis $\bullet$ & - & $10 \mathrm{~mm}$ & $12 \mathrm{~mm}$ \\
\hline Bacillus cereus $\bullet$ & - & - & $12 \mathrm{~mm}$ \\
\hline Pseudomonas aeruginosa $\bullet$ & - & - & $13 \mathrm{~mm}$ \\
\hline Staphylococcus aureus $\bullet$ & - & - & $9 \mathrm{~mm}$ \\
\hline Escherichia coli & - & - & - \\
\hline
\end{tabular}

\section{References}

[1] Amin Mir M, Sawhney S.S, Jassal M.M.S Qualitative and Quantitative analysis of Phytochemicals of Taraxacum officinali. Wudpecker Journal of Pharmacy and pharmacology 2013; vol. 2 (1) : PP 001-005

[2] Malini M, Abirami G, Hemalatha V, Annadurai G. Antimicrobial activity of Ethanol and aqucous Extracts of Medical Plants against waste water pathogens. International Journal of Research in pure and applied Microbiology , 2013 ; S(2) ;40-42

[3] Maluventhan Viji, Sangu Murugesan. Phytochemical Analysis and Antibacterial activity of Medicinal plant cardicspermum halicacabum Linn, Journal of Phytology . $2010 ; 2(1): 68-69$

[4] Prakash K Hedge, Harini A.Rao, Prasanna N. Rao. A review on Insulin plant ( Costus Igneus Nak). Pharmacognosy Reviews. 2014 Jan ; 8 (15) : 67-72

[5] Benny M . Insulin Plant in gardens . Natural product Radiance. 2004 ; 3 : 349-50

[6] Jose B Reddy LJ. Analysis of the essential oils of the stems, leaves and Rhizomes of the medicinal plant costus pictus from southern India. Int $\mathrm{J}$ Pharmacy Pharm Sci. 2010; 2 (suppl 2) : 100-1

[7] Devi VD, Urooj A Hypoglycemic potential of Morus indica. L and Costus igneus. Nak : A preliminary study. Indian J Exp Biol. 2008 ; 46: 614-616

[8] Ramya R, Daniel M. Phytochemical and Pharmacogostic investigation of antidiabetic Costus pictus D.Don. Int J Phar Biomed Res. 2012 ; 3(1) : 3039
[9] Melendez- Camargo ME, Castillo-Najera R, SilvaTorres R, Campor-Aldrete ME. Evaluation of the diuretic effect of the acueous extractof costus pictus D.Don in rat. Proc West Pharmacol Soc. 2006 ; 49: $72-$ 74

[10] Jothivel N, Ponnuswamy Sp, Appachi M, Singaravel S, Rasilingam D, Deivasigamani K. Antidiabatic activity of metanaol leaf extract of Costus pictus D.Don in alloxan-induced diabetic rats, J Health Sci. 2007 ; 53 : 655-63

[11] Saju Thomas, Seetha Devi B. Phytochemical and in vitro anthelmintec studies of hydro-alcoholic extract of costus pictus D.Don. International Journal of Pharmacy and Pharmaceutical sciences. 2013; vol 5(3) ; 639-641

[12]Brinda P, Sasikala P, Purushothaman KK. Pharmacognostic studies of Merugan Kizhangu. Bull Med. Eth. Bot.1981; Res. 3: 84-96.

[13] Siddiq Ali AA, Ali M. Practical Pharmaceutical chemistry. 1st ed. NewDelhi, CBS Publishers and Distributors.1997; 126-31

[14] Savithramma N, Linga RM, Bhumi G. Phytochemical screening of Thespesia populnea $(\mathrm{L})$ Soland and Tridax procumbens L.J. Chem. Pharm.2011; Res. 3: 2834

[15] Subashri B, Justin K oil Pillai. Acomparitive study of Antioxidant activity of Baccopa Monnieri (L.). Pennell Using Various Solvent Extract and its GC-MS Analysis. Int J Pharm Pharm Sci. 2014 ; Vol 6, Suppl 2, 494-498

[16] Ozkan G, Sagdic o, Baydar NG and Baydar H, Antioxidant and Antibacterial Activities of Rosa 


\section{International Journal of Science and Research (IJSR) \\ ISSN (Online): 2319-7064}

Index Copernicus Value (2013): 6.14 | Impact Factor (2015): 6.391

Damascena Flower Extracts, Food Sci Tech Int, 10 (4); 277-281, (2004).

[17] Janarthanam B and Sumathi E, Antimicrobial activity of Gymnema sylvestre leaf and callus. Journal of Tropical Medicinal Plants, 11(2) : 143-147, (2010).

[18]Lopez A Hudson JP and Towers GHN, Antiviral and antimicrobial activities of Colombian medicinal plants, J.Enthopharmacology, 77 : 189-196, (2001).

[19] Erturk O, Kati H, Yayli N and Demitirban Z, Antimicrobial Properties of Silene multifida (Adams) Rohrb. Plant Extracts, Turk J Biol, 30: 17-21, (2006).

[20] Mary Kensa V, Syhed Jasmin S. Phytochemical Screening and Antibacterial activity of Ricinus Communis L. Plant Sciences Feed. 2011 ; Vol (9) : 167173

[21] Johnson M, Maridass M, Irudayaraj V. Priliminary Phytochemical and Antibacterial studies on Passiflora edulis. Ethnobotanical Leaflets. 2008 ; 12 : 425-432

[22] Moremam DE . Native American Etnanobotany. Timber Press, Orge. $1998:$ 473-475

[23] Okwu DE , Josaiah C . Evaluation of the chemical Composition of two Nigerian Medicinal Plants. African Journal of Biotechnology 2006 ; 5 : 357-361

[24] Otokansi KC, Esimore Co and Anele CK . Evaluation of the invitro combined antibacterial effect of lead extract of Bryophyllum pinnatum and Ocimum oratissium. Plant Prod Res . J. 2005 : vol 9 : 23-27

[25] Palambo EA, Semple SJ . Antibacterial activity of traditional medicinal plants J Ethanopharmacol. 2001 ; 77: $151-157$ 